\title{
Movement of Cultural Objects In and Through Finland: An Analysis in a Regional Context
}

\author{
Suzie Thomas
}

\begin{abstract}
Mention of Finland, like many other northern European countries, is largely absent from discussions of the global trafficking of cultural objects. However, its proximity to the Russian Federation (historically a source of looted objects such as Orthodox icons and other religious art), as well as its apparent attractiveness as a route of transit, at least for the legal market in cultural objects, suggest that focus on Finland would be a valuable exercise in understanding the wider transnational movement of cultural objects, within the Baltic and Nordic regions and beyond. Indeed, the lack of any import regulation for cultural objects entering Finland, along with its pivotal role as a 'hard border' nation of the European Union and Schengen Area, suggest an 'invisible' problem, as yet under-researched and under-recorded. This paper aims to initiate discussion of the roles of seemingly unassuming nations within the backdrop of a regional and international context.
\end{abstract}

Keywords: Cultural objects, European Union, Finland, Russian Federation, Trafficking, Transit

\section{Introduction}

The licit and illicit movement of and trade in cultural objects, from archaeological material to fine and decorative arts, has been the subject of numerous publications. These studies have focussed on various regions and countries, and have engaged a range of different research methodologies (cf Brodie 2012 for an overview), and have identified source, transit and market countries as part of their narrative (e.g. Mackenzie and Green 2009: 1).

Aside from very occasional mentions of 'diplomatic bag' scandals (e.g. van Rijn 1993: 70), little has been said about Finland in relation to movement of cultural property. Conversely its neighbour, the Russian Federation, has been associated with theft and trafficking of cultural property such as Russian Orthodox icons in both Soviet times and in the period following the collapse of the Soviet Union (e.g. Ward 1992: 205-06). The movement of cultural objects between Finland and Russia is neglected in the literature despite it appearing to be a pressure point due to Russia's status as a third country (i.e. one out with the European Economic Area-EEA). Hence this particular border space is both an entrance and an exit to the EEA.

There is also extremely limited evidence in the literature of looted cultural objects from or involving Finland, a country which is also consistently ranked as having one of the lowest levels of state corruption anywhere (van Dijk 2007: 45, 47). Meanwhile studies of the border space between Russia and Finland have noted a more general media interest within Finland, depicting "images of undesirable elements, with smuggling, organized crime and the control of alcohol flows" (Paasi 2010: 673).

This paper, then, is unusual in the corpus of work examining the trafficking of looted cultural objects, by focusing on a country which is underrepresented in the literature. Certainly looting within Finland is smaller than in countries considered to be 'archaeologically rich' by comparison, or considered to have infrastructure problems that create conditions conducive to facilitating looting and smuggling. Equally, Finland's market for purchasing cultural objects, while not absent, is not generally perceived to be on the scale of some of its Nordic neighbours. For example, in such as Norway there are reports on individuals such as the private collector Martin Schøyen and controversy over the provenance over much of his extensive collection (Prescott and Omland 2003). Nonetheless, the absence of import legislation, as well as 
the geographical position of Finland, calls out for analysis. The paper, therefore, provides what might be seen as an 'introductory profile' of Finland in terms of its role, both acknowledged and unacknowledged, in the facilitation of illicit movement of cultural objects, particularly as a transit nation.

The issue of movement of cultural objects into 'third countries' from the European Union (EU) is particularly significant for Finland due to it having a "hard border" with a non-EU territory (Grabbe 2000). The policy of the EU to try to tackle transnational crime and illegal migrations, for example through the adoption of the Schengen Area, has been criticized by some as failing to protect victims, for example of human trafficking (Saari 2006). It is difficult to strike the balance between allowing free movement of EU citizens, and monitoring in any sort of detail what they may be taking with them. The way in which the border between Finland and Russia has been constructed and is strictly regulated, in comparison to the fluidity and openness of the Schengen Area border just a few hundred kilometres to the west between Finland and Sweden, has been noted elsewhere (Paasi and Prokkola 2008: 27).

In order to better understand the position of Finland, and the ways in which it might play a role in facilitating or curtailing the illicit movement of cultural objects, a number of questions can be asked. The literature suggests that attractive 'transit' countries are those which, amongst other things, may exert minimal levels of control on the import of art (including antiquities) and give official export papers to these objects when they leave (e.g. Bowman 2008: 233) thus performing something of an international 'laundering' service for provenance in art. What key identifiable features are there of the Finnish import/export regime for art, and are these comparable to identifiable traits of other transit countries? Taking a market vulnerability approach to the question of organized crime (see for example Mackenzie 2005), what would be the opportunities and hurdles for organized crime infiltrating the art market in Finland? What form might we predict organized crime would take to exploit market vulnerabilities? Finally, should more attention be focused on the so-called 'hard border' countries of the EU, given their role as a point of transit in the transnational movement of cultural objects?

Much of the data used in this paper flows from semi-structured interviews, primarily carried out in Helsinki but also in London and Tampere, which took place between August 2012 and April 2013. Some informants participated in small groups. The informants, whose interviews were recorded and transcribed in most cases ${ }^{1}$ comprised dealers and auctioneers, hobbyist metal-detector users, an archaeologist, an architect, an antiques collector, a security specialist, a politician, a conservator, a fine art consultant, representatives from the Finnish Border Guard and Police, the National Board of Antiquities (NBA), and the Ministry of Education and of fine art transporter companies. The data from the interviews was analysed, and is referred to for both general trends of response and specific examples.

\section{Finland as a Transit Country}

When thinking about the antiquities market, the role of so-called 'transit nations' is regarded as performing "a laundering role in respect of illicitly obtained objects by freely allowing them entry and then giving them permits when exported" (Mackenzie and Green 2009: 4). Where freeports exist, such as in Switzerland and Hong Kong, but also within the EU itself, they can provide an opportunity for generating papers, "which

\footnotetext{
${ }^{1}$ Two interviewees were not comfortable with being recorded, and so notes were taken during and immediately after the interviews to capture the issues discussed. One further interview took place over email due to the remote location of the informant and lack of opportunity to arrange a telephone interview.
} 
give the objects an appearance of legitimacy, in the form of export documents" (Polk 2009: 15). Atwood (2004: 97), for example, explains how the Swiss freeports have operated in such a way as to make it possible to add documentation to objects that states that they are from Switzerland, despite what their original (actual) provenance might be. Bowman (2008: 231) suggests that "some corruption on the part of customs inspectors, border patrol agents or law enforcement to facilitate cross-border movement" is also necessary.

In Finland there are two freeport areas at Lappeenranta (close to the Russian border) and Hanko (a sea port). The Hanko Freeport is almost entirely devoted to warehousing for cars (Freeport of Finland 2013), and similarly there is no clear indication of cultural objects moving through Lappeenranta. As noted above, corruption levels are among the lowest in the world. However, as noted below, this does not mean that cultural objects would still be checked at the border; it is far more likely that a Finnish official would simply not know to look for them, than that they would accept a bribe. Instead, reasons why transporter companies and others regarded Finland as a transit country were connected by other features. These included its physical location, importantly with good transport links such as well-maintained roads, as a neighbouring country to the burgeoning economy of the Russian Federation. Bogdanova (2011: 96), for example, has noted the growth in the art and antiques market within Russia from the 1990s onwards. Furthermore, legislation to require import licensing for cultural objects entering Finland does not exist, and cultural objects, or any other commodities that are simply passing through Finland do not require any export paperwork from Finland itself, although the 1994 Act (discussed below) legislates for the return of unlawfully removed cultural objects back to states within the EEA, through implementation of the Council Regulation of the European Communities on the export of cultural goods No. 3911/92 (Paukkula and Sihvo 2003: 108), for which a number of interim corrections have been published, as discussed below. This lack of import provision is not unusual, and as far back as the 1970s it was noted that very few countries have laws that prohibit import of art and other cultural material (Burnham 1975: 93). Furthermore, the application of licensing to specific categories of cultural object connected to the country is also a fairly common approach (Bator 1982: 286). With the absence of import documentation, and the export requirement only for objects with a connection to Finnish culture or its national history, or certain objects that have been in the country for at least 50 years (Paukkula and Sihvo 2003: 104), the role of Finland in providing legitimising paperwork for objects passing through, en route to other destinations, seems often to be absent. Tulli (Finnish Customs) staff confirmed that if the goods in question have already been cleared for export and exit in the country of dispatch and are being transited under the customs procedure of transit, then there will be no extra paper work or stamps in Finland. However, if the goods move from the country of dispatch to Finland in export procedure, and Finland is the customs of exit, then the export permit will be stamped at the border customs office in Finland. Unfortunately there is no information available on which of the two scenarios described occurs more frequently (Lampela 2013). Nonetheless, it is clearly not always the case that extra documentation is garnered by passing through Finland, especially if it is treated as a transit point.

The lack of import regulation also diminishes the possibility of halting trafficked antiquities before they arrive on Finnish soil. NBA staff recounted a case, which although rare demonstrates the difficulty of having no legislative tool to deal with import:

I think that it may be that cultural objects from EU are being transported to Russia through Finland. We had one case in which the Customs officers gave us a call and said that here is truck full of antiquities. The truck had originated from France, and the truck had been driving through Europe without anything else except a letter from an antiques dealer who said that these items do not require an export license. And when the truck came to Finland and was crossing the border to Russia, for some reason suddenly they decided that now they need the export license - these are antiquities - and they tried to get the export license from us. And this is one of the problems we 
have with our legislation that since these items had been imported to Finland, we don't have an import law prohibiting these kinds of objects being brought to Finland. (NBA 1)

Discussing the case again in a later interview, the same informant and another colleague revealed that while the responsibility lay ultimately with France as the point of origin for the objects, the French authorities never responded when contacted. Therefore, even though the European Council regulation, valid in Finland, would stipulate prevention of the objects in question from leaving the EEA without appropriate paperwork, in practice this did not happen. Organizational inertia on the part of their European counterparts, as well as cost, were seen as reasons not to detain what might be looted or at least illegally exported cultural objects from other EEA Member States:

[You couldn't impound the object until its license appeared from the country of origin?]

NBA 1: Well I had to think about this when the French case was active because it happened two or three years ago and I still haven't got a reply from France (laughs). In practice to stop these items at the border, they just can't do that. And the costs would be enormous, and I would have to have some kind of certainty that I will get a reply from the other country in a day or two.

[And I guess the owner could potentially sue?]

NBA 1: Exactly.

NBA 2: They can demand all sorts of compensation if it takes some time, and even if, and especially if they get the license. Yeah. It's another thing if they don't get the license, if they get no license this cannot leave the country, but if they get the license then maybe that the Finnish state will pay for, for the delay and things like that (laughs). It's not something you just jump in there (laughs). Many businesses involved with transporting fine art and antiques to Russia, on behalf of western auction houses and private dealers, use Finland as the transit route.

Interviewees in London indicated that in many cases experienced Finnish transporter companies would handle moving cargo from there into Russia, rather than the British companies trying to handle the often complicated Russian procedures. Hence, the transit issue does not necessarily accrue extra paperwork or indeed inspection for cultural objects, they merely travel through without any note or special examination. Finnish Police that were interviewed observed that it was highly unlikely that export paperwork would even be required for cultural objects that were simply passing through Finland.

In 2006, a report in Russian newspaper Pravda alleged that objects stolen from the State Hermitage Museum in St Petersburg were brought over land into Finland (Naumov 2006), suggesting that objects leaving Russia, especially as part of personal luggage, could travel into Finland with relative ease. From there, the leniency of the Schengen borders would presum- ably mean that any such objects could travel through the EU relatively easily. While on the one hand a 'legitimating' export licence from Finland would not be obtained in the way that such licenses can be issued from freeports, the comparative unlikelihood of the object being checked within the Schengen Area under the current parameters of the Schengen Borders Code (European Commission 2006) presumably reduces the risk of the license being needed anyway.

\section{Finland Close to Russian Organized Crime}

A rather pressing concern for security studies in Finland, but also the whole of the EU, is the planned visa waiver between the EU and the Russian Federation by 2020. The aim that within the next decade an 
agreement will have been reached on the implementation of this (Gromyko 2013) has obvious implications for economic development, but also for the facilitation of transnational crime. In Finland, as a 'hard border' nation of the EU, implementation will be particularly significant:

I don't want to even think about, because what happens. After that we are backyard for the Russian criminal groups. (Finnish Police 1)

Bäckman suggested that for within Finland itself:

By far the most sinister threat is the integration of the Finnish and the Russian underworlds. Russian criminals need Finnish colleagues in order to operate in Finland. Both economic criminals and gangland bosses can look for mutual opportunities. (Bäckman 1998: 25)

This, he indicated, would be difficult to detect in official statistics, being effectively 'hidden crime', or as others have named it, part of the "dark figure" missing from official statistics (MacDonald 2002: F86). There are obvious parallels here when considering the illicit trade in cultural objects more broadly and the challenges in establishing exact figures as to the scale and cost of the criminal market (e.g. Brodie 1999).

Bäckman's observation about needing to utilise Finns in order to operate within Finland was borne out in interviews. An obvious reason for this is the difficulty of the Finnish language, and the unlikelihood of non-Finnish citizens being able to speak it. Another reason is the inherent mistrust that seems to exist, especially in the art and antiques market, of buying from Russian and other former Soviet nationalities. Finnish police investigating a case involving smuggled faked paintings concluded that:

Finnish Police 2: ...if we want to do a fraud with the fake painting here in Finland, you must have the Finnish people.

Finnish Police 1: Of course.

Finnish Police 2: Because they need to all the time, Finnish people, Finnish clients don't buy fake paintings straight from the Russian people, they don't trust them. They,

Finnish Police 1: Also they don't buy real paintings.

Finnish Police 2: Even real paintings,

Finnish Police 1: You have to have, some,

[So you need a sort of Finnish face, if you like, to,]

Finnish Police 1: Yeah,

Finnish Police 2: Yeah yeah yeah, and Finnish story and Finnish language you must have that, and they, that's the only way to do this fraud, I think so.

The sentiment against buying from former Soviet nationalities, based on perceived reputation and often to do with experiences in the years following the Soviet Union's collapse, was echoed by a number of auctioneers:

I wouldn't even touch anything coming out of Latvia today. Every time we have had something interesting turning up there has been an ownership issue. And, and the reason for that was that, that during the Soviet period, Riga was a centre for dealing with antiques in the Soviet Union. So people used to come, bring things to Riga, and exchange and trade, and from all, from all over Soviet Union. So Riga had quite a lot in, in 1990 when they became independent, which very quickly was sold and dispersed to different areas of Europe. (Finnish Auctioneer 2) 
On the other hand, if the provenance had convincing evidence attached to it, or had a provenance placing it in a Finnish context, this seemed to be acceptable to many would-be buyers or handlers, a fact exploited by criminals:

...because when you are doing with this false paintings, you can't, you don't do anything about, if you have just painting, it's nothing. You have, you must have this story, the provenance, and, and together, you take this, it is the equipment what you use to do that fraud. But you have must very good story, and these guys, they take, they spend a lot of time and a lot of money to do very good story.

[So their stories, if they're putting a lot of time into it, are they including paperwork and things?]

Yeah. And manipulated pictures and so on. (Finnish Police 2)

Essentially, then, Finnish actors such as art and antiquity dealers and gallery owners can be recruited as 'facilitators' to enable the selling of fake and other questionable art objects, often with supporting 'evidence' such as doctored photographs implying a longer history for the painting than is really the case. This use of facilitators within the trade of illicit antiquities and art, but also within money laundering networks generally, is noted elsewhere (Mackenzie 2011: 79-80).

A major barrier to curtailing the movement of fakes was identified as being the inability of Finnish enforcement agencies under current legislation to confiscate fake art, meaning that it continues to circulate on the market even if it has previously been identified as a fake. A case under investigation at the time of interviewing centred on the involvement of a known Finnish organized crime group in the trafficking of faked paintings, mostly originating from Russia. Their presumed method of transport into Finland, usually via Estonia, confirmed the avoidance of formal cargo consignments:

Finnish Police 2: I think if, if they are preparing some huge fraud, then they are just one painting at a time, because,

[So it could even go in hand luggage?]

Finnish Police 1: Yeah, it's just, it's normal. But if you have one truck, it's more of paintings,

Finnish Police 2: It's quite easy to bring in this painting because without the frames you can just (rolls up piece of paper).

Interestingly enough, the practice of rolling smuggled paintings was noted by one of the auctioneers interviewed, including common mistakes made by less experienced smugglers:

... there are giveaway signs. You can see, see the crack, where, the crack when they rolled up, and they were usually rolled up the wrong way. You have to roll the paintings so that the artwork is outside and not inside because of cracks if you roll the picture. You think you protect the picture that way, but you don't. You have to do it the other way because you stretch the oil paint when you roll it the other way, when you try and squeeze it, it cracks. (Finnish Auctioneer 2)

The smuggling case, which was in court in Turku in early 2013, resulted in a conviction only for one of the defendants, a Finnish artist and art dealer who had been used to act as a front through which to sell the fake paintings, many of which were passed off as the work of high-end artists such as Picasso. The schematics of the trafficking route under investigation were shown to the author, including the hypothesised route from St Petersburg via Estonia to Finland, and then on to Sweden, France and England, as well as the names of individuals and organizations (among them private galleries and large auction houses), both wittingly and unwittingly involved. However, the case was still, at the time of writing, part of 
a larger investigation (which may well reveal yet more trafficking networks), and hence permission was not granted to reproduce the diagram.

The police who were interviewed noted that contact with colleagues in police forces in other countries was important, although often this was based on personal contacts at an individual level. Crossborder collaboration could also be hampered by differences in procedures and requirements. Research in progress at the University of Helsinki focusing on cross-border collaboration indicates that there are positive steps in terms of developing practical cooperation between police in both Russia and Finland, although fundamental differences in procedure and legislation continue to create barriers to transnational criminal investigations (Heusala and Koistinen 2013).

This concern about the limitations presented by conflicting national procedures for identifying transnational criminals and their activities, as well as measures to address this through training and collaboration, is observed in transnational policing generally (e.g. Andreas and Nadelmann 2006: 171-72).

\section{Domestic Theft and Looting in Finland}

Bator (1982: 286) has noted that illegal export can occur with or without the object in question being originally stolen, and that determining whether theft or looting has occurred can become complicated. There is very little information about the extent of looting within Finland. Across the Baltic and Nordic regions as a whole, increases in internet trading, the impact of the Schengen Treaty, and the availability of cheaper metal detectors have been cited as recognized threats to cultural heritage (Lehtimäki 2011: 13). Individual anecdotes from the interviews also pointed to awareness of occasional illegal excavation, sometimes known only through word of mouth and rumour, and, while the Finnish Border Guard had little input into the hands-on control of movement of cultural objects from land, there seemed, in contrast, to be specific awareness within the Border Guard of the risk of looting and theft faced by protected historic shipwrecks. There was even impetus to check suspect boats for pieces of looted wreck alongside the other items routinely searched for.

Some thefts of cultural objects are also documented, for example the theft of an Orthodox icon from Helsinki's Uspenski Cathedral in 2010 (Helsingin Sanomat 2010), which was subsequently recovered, or the theft of rare maps from the University of Helsinki Library in 2001 (Fleet 2003: 10). These sorts of thefts, however, are rare.

Regionally, there are questions of repatriation concerning indigenous Sami cultural property (and see Recalling Ancestral Voices 2006 for a recent project addressing some of these issues). The remains of both World Wars, and the associated Civil War (1918) and Winter War (1939-1940), are also exposed to unrecorded removal. Seitsonen and Herva noted in their own ongoing research into Second World War Prisoner of War camps in Finnish Lapland that there are local community desires to "clean" the wilderness of what is perceived as "war junk", exacerbated by "exploitation by collectors of war memorabilia" (Seitsonen and Herva 2011: 178).

Interviews indicated that other modern cultural objects are also becoming vulnerable to theft and subsequent illegal export (and see Thomas 2014 for a more indepth discussion of this phenomenon). In an unusual case in 2012, the Finnish government requested the return from the UK of a piece of architecture from a building in Helsinki designed by the modernist architect Alvar Aalto (Helsingin Sanomat 2012). This was the theft, illegal export and eventual appearance in a Christie's catalogue in London with a fabricated provenance (2012: Lot 84), of a rail support from the Erottaja Pavilion in central Helsinki, constructed in 1951-52. The object came to the notice of officials when an export licence was applied for retrospectively. 
One informant suggested that the theft of architectural features connected to famous designers extended to the frequent (and apparently easy) removal of door handles from architecturally significant buildings such as the Vuoksenniska church in Imatra, and the Otaniemi Campus buildings of Aalto University. One explanation for this, aside from opportunist souvenir taking, was that such objects automatically fetch higher prices once abroad. Vintage designer furniture, commonplace in Finnish public buildings but highly desirable abroad, is susceptible for the same reason. One informant, an antiques dealer, told an anecdotal story (unrecorded) of a friend who had stolen a 1930s Alvar Aalto-designed stool made by Artek from a leisure centre by unscrewing the component parts and placing them into a rucksack, subsequently selling the piece to a foreign collector. At the Paimio Sanatorium in Turku, another informant explained, they have taken the measure of chaining the collectible furniture to the walls to prevent illegal removal. Another point made by some of the Finnish auctioneers interviewed was that the discrepancy between the relatively modest prices fetched within Finland and the very high prices made on the international market for vintage Finnish design could add financial incentive for illegally exporting restricted pieces. This, coupled with the significant unlikelihood of the objects being checked or even identified on the border by officials, made illegal export extremely tempting.

\section{Regulation and Codes of Practice}

A separate study of preventing illegal export of cultural objects from Sweden broadly identified factors obstructing regulatory compliance, such as dealers feeling that current export application processes were too complex, limited resources for the authorities concerned with exporting, and the relatively lax border control within the EU (Johannson and Korsell 2012: 13-14). Many of these identified challenges corresponded closely to the situation found in Finland.

The export of cultural objects originating from Finland is managed primarily through the NBA with a network of museums including the National Museum of Finland, Ateneum (the National Gallery) and the Design Museum.

Export is controlled by the Act on Restrictions to the Export of Cultural Objects 115/1999. The Act "applies to objects produced in Finland or to such objects... ...produced abroad which have been in Finland for at least 50 years during the last 100 years", and covers export from Finland to other EU member states and also "export from the territory of the community". Additionally, "if an object produced abroad has special value from the standpoint of Finland's national history, this Act shall be applied to the object irrespective of the duration it has been in Finland". Some special categories of object, such as "original or comparable products of industrial art and art handicraft" require an export license if they are over 50 years old, whereas other categories must be over 100 years old (Paukkula and Sihvo 2003: 104).

In addition to the export laws, the Antiquities Act 295/1963 provides a legal framework for the management and protection of archaeological sites and materials within the Finnish territory. Portable objects covered under this Act are those "which can expect to be over 100 years old" (National Board of Antiquities 2013).

Two of the key international legislative tools for tackling the international traffic in illicit cultural objects are the UNESCO 1970 Convention and the Unidroit 1995 Convention, with the latter designed to complement the former through its focus on private and national laws (Prott 1996: 60). The Unidroit Convention was brought into force in Finland on 1 December 1999, having been ratified on 14 June 1999. The Act was brought into force by the Decree for bringing into force the Unidroit Convention on Stolen or Illegally Exported Cultural Objects and adopting certain regulations of the Convention and the entry into force of the Act on the application of the Convention 878/1999 (Paukkula and Sihvo 2003: 112). 
On 28 May 1999, Finland and Åland (a Swedish-speaking autonomous dependency of Finland) ratified the UNESCO 1970 Convention through the Decree for bringing into force the Convention on the Means of Prohibiting and Preventing the Illicit Import, Export and Transfer of Ownership of Cultural Property and the entry into force of the Act on adopting certain regulations of the Convention 876/1999. Under this Decree, "the Government of Finland declares that it shall implement the regulations of Article 7 paragraph b subparagraph ii of the Convention in accordance with the obligations set by the Unidroit Convention" (Paukkula and Sihvo 2003: 110).

Article 7 is observed elsewhere as having been inserted into the Convention to provide specific procedures and essentially restrict the scope of Article 3, which had been a point of concern for States where there has always been a large trade in cultural objects (Prott 1996: 62). The specific reference to Article 7 (b) (ii) for Finland (see also UNESCO undated) focuses on the restitution of cultural objects and the compensation to "an innocent purchaser" (UNESCO 1970), relying more on the Unidroit Convention than the UNESCO Convention over all for this specific element of implementation (Paukkula and Sihvo 2003: 110).

As Finland has a national ICOM Committee, it may be presumed that the obligations of museums are covered under the ICOM Code of Ethics, although at the same time such codes do not have the same force or effect as obligations under such as an international convention. However, as O'Keefe and Patrick (1997: 97) point out, such codes can nonetheless be effective, especially if they are publicized more widely thereby putting people "on notice as to what conduct is unacceptable, even by those outside the organizations concerned".

The role of the ICOM Code of Ethics is reinforced by the fact that internal regulations and statutes of museums in Finland make specific reference to the ICOM Code of Ethics (Armbrüster et al. 2011: 153). Of other States to deposit instruments regarding the 1970 UNESCO Convention, only three, other than Finland, have made declarations or reservations regarding Article 7 (b) (ii). Guatemala expressed reservations regarding the implied obligation of the State to pay compensation to good faith purchasers, while the USA and the UK both made specific mention of the subparagraph, with regard to recognising it to the extent that it is in line with existing legislation (UNESCO undated).

As noted earlier, provisions of Council Regulation (EEC) No. 3911/92 on the export of cultural goods apply in Finland (Paukkula and Sihvo 2003: 107). An update in the form of Council Regulation (EC) No $116 / 2009$ on the export of cultural goods was implemented, following amendments to the original Regulation. Further changes are proposed, among other things to extend the deadline for initiating return proceedings to 3 years, which would bring it in line with the requirements of the Unidroit 1995 convention, Article 3 paragraph 3. The new Directive is expected to come into effect in 2015 (European Commission 2006), although it was noted by one informant in interview that the discussions required to bring about these sorts of changes usually took a long time to be processed.

Further laws affecting movement of cultural property within Finland include the Act on the return of cultural objects unlawfully removed from the territory of a Member State of the European Economic Area $1276 / 1994^{2}$, which legislates for the return to Member States of the EEA any cultural objects found to be in Finland that have been found to have been unlawfully removed from another Member State.

There are international codes of practice applicable to traders of cultural objects, such as the Code of Ethics of the International Confederation of Art and Antique Dealers Associations (CINOA) or the International Code of Ethics for Dealers in Cultural Property of UNESCO, although as noted elsewhere the

\footnotetext{
${ }^{2}$ See http://www.unesco.org/culture/natlaws/media/pdf/finland/fi_actreturneuroecoarea1994_engtno.pdf for an unofficial translation
} 
application of these codes is sporadic at best (Armbrüster et al. 2011: 153). The Sveriges Konst-och Antikhandlareförening (SKAF) is affiliated to CINOA and thus adopts its Code of Ethics (SKAF 2013). Most of SKAF's membership are dealers based in Sweden, although two businesses based in Helsinki are also members. An association exists for Finnish dealers of art and antiques, Suomen Taide- ja Antiikkikauppiaiden liitto (STAY), but this organisation would seem to be more concerned with organising fairs, although very little information is available. One of the informants interviewed felt that many dealers in Finland actively preferred not to find out too much about provenance of items that they bought to sell on, so as to avoid the risk of knowing about potentially tainted origins.

\section{Border Control}

A report published by the Brottsförebyggande rådet (Brå - the Swedish National Council for Crime Prevention, Information and Publication) presented the results of the first pan-Nordic survey into the extent of crimes affecting cultural heritage, having analysed data from Norway, Denmark, Sweden and Finland (Korsell et al. 2006). The report shed light on the extent of crimes within the Nordic nations affecting cultural heritage, but it deliberately did not deal with illegal import (Korsell et al. 2006: 10).

Export licenses granted for cultural objects by the Finnish authorities, including fine art, usually average around 20 per year with only six export licenses refused between 2008 and 2012. Interviews almost uniformly confirmed, regardless of the role of the informant, that in Finland it would be unlikely for people leaving at the border points, whether the land borders with Sweden, Norway or Russia, or through the seaports and airports, ever to be checked for cultural property on their person or in their luggage or vehicles:

I think everybody agrees that it's not under control (laughs). (Ministry of Education 1)

Informants from the Finnish Border Guard also suggested that not only might it be unclear what even to look for in terms of types and appearance, but that it was unlikely that cultural objects would be looked for anyway, due to other, higher priorities. It was felt by most informants that checks are more thorough generally where freight is involved, which would fall to Customs rather than to the Border Guard. In addition, as noted in studies of other jurisdictions and markets (Mackenzie 2005: 154) self-regulation, through monitoring one's own practice, often with the threat of more formal sanctions for non-compliance, was identified as a key means of controlling the larger scale export of cultural objects. While the fluid borders within the EU were acknowledged by many to offer little in terms of physical control of flow of cultural objects (especially small quantities within luggage as noted above), the longer term requirement to show an object's legitimacy of provenance, apparently imposed by improving standards of provenance checking within auction houses themselves, was seen by some auctioneers as a deterrent from contravening export requirements despite the ease of doing this on the short term.

Even international requirements such as Article 7 (b) (i) of the UNESCO Convention regarding inhibiting import of inventoried objects stolen from museums and other institutions, (which as noted above is not subject to Finland's 1999 Decree), despite concerns by some "surrealistic" interpretations of the paragraph, would not in practice require the checking, for example, of all luggage entering a Contracting State. (O'Keefe 2007: 58) suggests that customs services can use less exhaustive measures such as using profiles and spot checks. Informants from the Finnish Border Guard believed that the profiles currently used to target smugglers of people, alcohol or tobacco, would be unlikely to fit the imagined profiles of cultural object smugglers, and hence current application of profiling would be unlikely to detect trafficked cultural objects. 
Resources such as databases of known stolen property, which can theoretically be consulted by border agencies, were also criticized by interviewees. One informant from the NBA observed that on one occasion when they had informed Interpol of stolen cultural objects from a Finnish manor house, the reaction had been extremely slow and the objects had been recovered before they even appeared on the database.

\section{Conclusions}

In many ways, this paper lays the foundations for a more focussed programme of study of the Baltic and Nordic regions in terms of suggesting barriers to effective regulation of the movement of cultural objects. Even at a supply level, there are indications that specific categories of cultural objects originating from Finland are vulnerable to demands from overseas, notably (but not exclusively) material culture from the wars of the twentieth century, and the highly collectible vintage examples of Finnish design, some of which are ostensibly protected from unregulated export by law.

Detailed analysis is particularly timely given the raft of political and structural changes experienced by the region due to events such as the fall of the Soviet Union, accession of a number of states to the EU and the further economic and regulatory transitions likely to materialise in the coming decades. There would appear to be not only existing legislation but also scope to add more, for example through the planned changes to the EC Directive on the export of cultural goods, as well as an acknowledged (by the NBA at least) need for import regulation. It is also apparent from interviews with a range of actors that the existing regulation, in practice, is currently limited. This has been due to perceived greater priorities in controlling other criminal markets, but also perhaps a certain degree of apathy as to the perceived benefits of taking action.

The case of Finland sheds light on the possibilities that exist, and in the case of economic crimes involving the smuggling of faked artwork, that are being utilised already, for the apparent ease of moving cultural objects across the borders.

Returning then to the questions posed at the start of this paper, a number of identifiable features in Finland exist that indicate its status as a 'transit' country, in the traditional sense. These are namely legal, geographical, authority capacity, and perception factors. It opens the suggestion, then, that these indicators, divided into types of factor, may usefully be used to identify what are effectively transit countries due to their specific conditions.

For Finland, the main legal factor that comes into play is that there is no import regulation at all. This is comparable to many other countries, and while export regulation exists, it is largely based on trust, being the responsibility of the exporter to apply for the license from the relevant organisation. Despite the fact that there is rarely a 'laundering' facility in the sense of provision of licenses to exiting objects (removing its role as a legitimating facility for looted and stolen material), the lack of checks, even in the absence of significant organizational corruption, means that movement through the country of objects originating elsewhere is relatively unhindered.

The geographic factor is primarily position, like Finland, at the interface between the EU and a third county, Russia, which will only become more significant should the plans for a visa-free agreement by 2020 come to fruition. This has implications for all forms of transnational crime.

The authority capacity factor is mainly that the current focus by border authorities in Finland on other forms of trafficking and smuggling such as of humans and alcohol, while understandable, suggests that the gaze of key organizations is currently fixed elsewhere. This is different to other transit situations 
noted by others (e.g. Bowman 2008) where state corruption plays a part in facilitating movement of illicit cultural objects, but nonetheless has a similar effect in terms of reducing the likelihood of action being taken against transporters. In such conditions where the attention of nonetheless competent authorities is directed elsewhere, it suggests that the non-freight movement of smaller cultural items becomes a very low-risk criminal activity.

Finally, with regard to perceptions, as noted by the Finnish police in the smuggled art work case, and by Bäckmann (1998), the reputation of Finns as reliable and law-abiding can be used in some cases to create the impression of legal business transactions, where actually the objects being traded have an illicit background. The widely-held perception seems to be that an object that passes through Finland is clean with Finnish involvement in the transaction apparently sanitising the deal in some cases.

In terms of predicting how organized crime would look in Finland, against the art market's vulnerabilities, it is notable that Finnish police have already identified links between organized criminal groups in both Finland and Russia and the movement of faked artwork. Furthermore, as noted in both literature and interviews, the inherent mistrust of Russian and other sources as opposed to seemingly dependable Finnish sources suggests that for any criminal networks to operate in a way that engaged the art and antiques markets in Finland would have to involve actors of Finnish origin.

In conclusion, given the relatively unresearched nature of the market in cultural objects involving Finland, despite its geographic location and apparent paucity in barriers to illegal export and illicit transit, more attention should be focussed on Finland, and the 'hard border' regions of Europe more generally. Consideration of atypical 'source' countries (in economic and archaeological senses), is another area requiring further examination, lest still vulnerable cultural property go overlooked in favour of the more high profile categories of cultural object from other parts of the world.

\section{Acknowledgments}

This research forms part of the suite of research into the global trafficking of cultural property through 'Trafficking Culture', which has received funding from the European Research Council under the European Union's Seventh Framework Programme (FP7/2007-2013)/ERC Grant agreement no 283873. The author would also like to thank the University of Glasgow's School of Social and Political Sciences for an International Partnership Development Fund grant enabling fieldwork in Finland, and the Department of Archaeology at the University of Helsinki for hosting a Visiting Fellowship in 2013. Finally, thank you to Dr Christa Roodt for comments on drafts of this paper.

\section{References}

Andreas, P., \& Nadelmann, E. (2006). Policing the Globe: Criminalization and Crime Control in International Relations. Oxford: Oxford University Press.

Armbrüster, C., Beauvais, P., Chedouki, J., Cornu, M., Fortis, É., Frigo, M., Fromageau, J., Maget-Dominice, A., Negri, V., Renold, M., \& Wallaert, C. (2011). Study on preventing and fighting illicit trafficking in cultural goods in the European Union. Brussels: CECOJI-CNRS.

Atwood, R. (2004). Stealing History: Tomb Raiders, Smugglers, and the Looting of the Ancient World. New York: St Martin's Press. 
Bäckmann, J. (1998). Russian Crime and Finland. In J. Bäckmann (Ed.), The Inflation of Crime in Russia (pp. 20-30). Helsinki: National Research Institute of Legal Policy.

Bator, P. M. (1982). An essay on the international trade in Art. Stanford Law Review, 34, 275-384.

Bogdanova, E. (2011), 'Valuing the Past: The Constitution of the Antiques Market in Russia', (Universität zu Köln).

Bowman, B. A. (2008). Transnational crimes against culture: looting at archaeological sites and the 'Grey' market in antiquities. Journal of Contemporary Criminal Justice, 24(3), 225-242.

Brodie, N. (1999). 'Statistics, Damned Statistics, and the Antiquities Trade', Antiquity, 73, 447-51. -- (2012), Uncovering the Antiquities Market. In R. Skeates, C. McDavid, \& J. Carman (Eds.), The Oxford Handbook of Public Archaeology (pp. 230-252). Oxford: Oxford University Press.

Brodie, N. (2012). Uncovering the Antiquities Market. In R. Skeates, C. McDavid, \& J. Carman (Eds.), The Oxford Handbook of Public Archaeology (pp. 230-252) Oxford: Oxford University Press.

Burnham, B. (1975). The Art Crisis (London: Collins). Christie's (2012), '20th Century Decorative Art \& Design', in Christie's (ed.). London: Christie's.

European Commission (2006), 'Regulation (EC) No 562/2006', in European Commission (ed.).- (2013), 'Single market for goods: Return of cultural goods', (updated 6th June 2013) <http://ec.europa.eu/ enterprise/policies/single-market-goods/internal-market-for-products/cultural-goods/>, accessed 24th June 2013.

Fleet, C. (2003). Report on the 13th conference on "strategies for survival: collections, data, institutions" of the groupe des cartothécaires de LIBER, 3-7 september, Helsinki, Finland. LIBER Quarterly, 13(1), 8-20.

Freeport of Finland (2013), 'Freeport of Finland Ltd', <http://freeport.fi/index.php?id=fpenglish>, accessed $20^{\text {th }}$ November 2013.

Grabbe, H. (2000). The sharp edges of Europe: extending schengen eastwards. Int Aff, 76(3), 519-536.

Gromyko, A. (2013), 'Europe 2020: What's in Store for Integration?', Russian Foreign Policy: Analysis (updated 20th March 2013) <http://russiancouncil.ru/en/inner/?id_4=1575\#top>, accessed 18th June 2013.

Helsingin Sanomat (2010), 'Valuable icon stolen from Uspenski Cathedral', Helsingin Sanomat, 9th June 2010.

Helsingin Sanomat (2012), 'Kadonnut Aalto-kaide löytyi Lontoosa', Helsingin Sanomat, 17 November 2012, p. 1.

Heusala, A.-L., \& Koistinen, J. (2013), 'Development of Russian Law Research Methodological Seminar', International Economic Law Seminar Series (University of Helsinki).

Johannson, H. S., \& Korsell, L. (2012), 'Preventing illegal export of cultural objects: A summary of report 2012: 10', (Stockholm).

Korsell, Lars, et al. (2006), 'Cultural Heritage Crime: the Nordic Dimension', (Stockholm: The Swedish National Council for Crime Prevention, Information and Publication).

Lampela, H. (2013), 'VS: Customs procedure question', email correspondence. 
Lehtimäki, M. (2011). Looting and Illicit Trade in Cultural Heritage - Problems that cannot be solved by one state or one sector alone. In A. Chabiera (Ed.), Stop Heritage Crime: Good practices and recommendations (pp. 13-14). Warsaw: Narodowy Instytut Dziedzictwa.

MacDonald, Z. (2002). Official crime statistics: their Use and interpretation. Econ J, 112(477), F85-F106.

Mackenzie, S. (2005). Going, Going, Gone: Regulating the Market in Illicit Antiquities (Leicester: Institute of Art and Law).

Mackenzie, S. (2011). The market as criminal and criminals in the market: reducing opportunities for organized crime in the international antiquities market. In S. Manacorda \& D. Chappell (Eds.), Organized Crime in Art and Antiquities (pp. 69-85). New York: Springer.

Mackenzie, S., \& Green, P. (2009). Introduction. In S. Mackenzie \& P. Green (Eds.), Criminology and Archaeology: Studies in Looted Antiquities (pp. 1-10). Oxford: Hart.

National Board of Antiquities (2013), 'The Antiquities Act', <http://www.nba.fi/en/cultural_environment/archaeological_heritage/official_protection/the_antiquities_ act\#ancient>, accessed 13 February 2013.

Naumov, A. (2006), 'The stolen masterpieces were taken abroad in a string-bag', Pravda (updated 7 August) <http://english.pravda.ru/history/07-08-2006/83787-hermitage-0>.

O’Keefe, P. J. (1997), Trade in Antiquities: Reducing Destruction and Theft (London: Archetype).

-- (2007), Commentary on the UNESCO 1970 Convention on Illicit Traffic (2nd edn.; Builth Wells: Institute of Art and Law).

Paasi, A. (2010). Boundaries as social practice and discourse: the Finnish-Russian border. Reg Stud, 33(7), 669-680.

Paasi, A., \& Prokkola, E.-K. (2008). Territorial dynamics, cross-border work and everyday life in the FinnishSwedish border area. Space and Polity, 12(1), 13-29.

Paukkula, I., \& Sihvo, P. (2003). 'Kultuuriesineiden Maastavienti/Utfösel och Export av Kulturföremål/Export of Cultural goods', in National Board of Antiquities (ed.). Helsinki: National Board of Antiquities.

Polk, K. (2009). Whither Criminology in the Study of the Traffic in Illicit Antiquities. In S. Mackenzie \& P. J.

Green (Eds.), Criminology and Archaeology: Studies in Looted Antiquities (pp. 13-26). Oxford: Hart Publishing.

Prescott, C., \& Omland, A. (2003). The schøyen collection in Norway: demand for the return of objects and questions about Iraq. Culture without Context, 13, 8-11.

Prott, L. V. (1996). unesco and unidroit: a partnership against trafficking and cultural objects. Uniform Law Review, 1, 59-71.

Recalling Ancestral Voices (2006), 'Repatriation', (updated 2006)

<http://www.samimuseum.fi/heritage/english/repatriaatio.html>, accessed 27th June 2013.

Saari, S. (2006). 'Balancing between inclusion and exclusion: The EU's fight against irregular migration and human trafficking from Ukraine, Moldova and Russia', LSE-Challenge Working Papers. London: London School of Economics. 
Seitsonen, O., \& Herva, V.-P. (2011). Forgotten in the Wilderness: WWII German PoW Camps in Finnish Lapland. In A. Myers \& G. Moshenska (Eds.), Archaeologies of Internment (pp. 171-190). New York: Springer/One World Archaeology.

SKAF (2013), 'IF SKAF', <http://www.konstantik.se/about-skaf>, accessed 24th June 2013.

Thomas, S. (2014), 'Vulnerable by design: Theft and Finnish Architecture', The Historic Environment Policy and Practice, 5 (1).

UNESCO (1970), Convention on the Means of Prohibiting and Preventing the Illicit Import, Export and Transfer of Ownership of Cultural Property. -- (undated), 'Declarations and Reservations: Convention on the Means of Prohibiting and Preventing the Illicit Import, Export and Transfer of Ownership of Cultural Property 1970', <http://portal.unesco.org/en/ev.php-

URL_ID=13039\&URL_DO=DO_TOPIC\&URL_SECTION=201.htm|\#RESERVES>, accessed 27th June 2013. van Dijk, J. (2007). Mafia markers: assessing organized crime and its impact upon societies. Trends in Organized Crime, 10(4), 39-56.

van Rijn, M. (1993). Hot Art, Cold Cash. London: Warner Books.

Ward, B. (1992). The second international art, antique and architectural theft conference held by trace magazine and the Georgian group, London 8-11 June 1992. Int J Cult Prop, 2(1), 203-207. 